\title{
Feral horse seasonal habitat use on a coastal barrier spit
}

\author{
RICHARD D. RHEINHARDT AND MARTHA CRAIG RHEINHARDT
}

Authors are Research Assistant Professor, Department of Biology, East Carolina University, Greenville, N.C. 27858; and Senior Wetland Scientist, Vine Associates, 18 Beach Street, PO Box 555, Monument Beach, Mass. 02553. At the time of the research, junior author was Adjunct Scientist, Department of Biology, East Carolina University, Greenville, N.C.

\section{Abstract}

Management of feral horses grazing on Atlantic and Gulf coast barrier islands requires information on seasonal habitat preferences and distribution of important forage species to maintain stable populations and prevent destruction of fragile island ecosystems, particularly as coastal development further restricts free range. Counts from seasonal aerial surveys of Currituck Banks, N.C. were used to determine whether particular habitats were used more or less than would be expected by chance. On-ground observations were used to determine the relative intensity of grazing on vegetation by habitat and season. Feral horses showed seasonal preferences for particular forage species and habitat types. Horses grazed upon at least 16 graminoid and 5 forb species across 6 identified habitat types covering 4,619 ha. In late winter, Maritime Forest was used significantly more than expected while Tidal Freshwater Marsh was used less than expected. In spring, all habitats were used in the proportion expected based on availability. In early summer, Wet Grassland was preferentially used while Dry Grassland was preferentially avoided. The relative degree of exposure from wind may explain why horses spent less time than expected in exposed marshes during winter and more time than expected in forest. The availability of fresh water and hydrophytes may explain why horses spent more time than expected in Wet Grassland in summer and less time than expected in Dry Grassland. Seasonal habitat preferences should be considered when managing for ecosystem sustainability of feral horses on barrier islands.

Key Words: barrier island, forage, grazing, North Carolina, preferential habitat utilization, seasonal utilization

Since the early 1700 s, inhabitants of coastal regions in the southeastern USA have used coastal barrier islands as free range for livestock. This continued even after fence laws were enacted in the late $1800 \mathrm{~s}$. Widespread use of coastal areas ended as resort development expanded in the mid-1900s. However, feral horses (Equus caballus) and pigs (Sus scrofa) have continued to persist on more isolated barrier islands, primarily on public lands.

Management of wild horses on public lands has become controversial (Cook 1975). Public concerns for the welfare of feral horses have led to federal protection at the same time that natural resource agencies are increasingly concerned about potential grazing impacts of horses and pigs on native vegetation.

Research was funded by the National Estuarine Research Reserve of North Carolina Department of Environment, Health, and Natural Resources. Airplane time was provided by the U.S. Department of the Interior Fish and Wildlife Service.

Manuscript accepted 3 Sept. 03.
Resumen

El manejo del apacentamiento de caballos salvajes en las islas cercanas de la costas del Océano Atlántico y el Golfo requiere de información sobre las preferencia estacionales de hábitat y la distribución de las especies forrajeras importantes para mantener poblaciones estables y prevenir la destrucción de los frágiles ecosistemas de las islas, particularmente conforme al desarrollo costero restringe más el libre movimiento de los caballos. Se utilizaron conteos de reconocimientos aéreos estacionales efectuados en Currituck Banks, N.C. para determinar si hábitats particulares fueron utilizados más o menos que lo sería solo por cuestiones aleatorias. Se usaron observaciones terrestres para determinar la intensidad relativa del apacentamiento en la vegetación por hábitat y estación del año. Los caballos salvajes mostraron preferencias estacionales para ciertas especies forrajeras y tipos de hábitats. A través de 6 tipos de hábitats identificados, cubriendo 4,619 ha, los caballos apacentaron al menos 16 especies de gramíneas y 5 especies de hierbas. A fines de invierno, el bosque marítimo fue usado significantemente mas de los esperado mientras que las marismas de agua dulce se usaron menos de los esperado. En primavera todos los hábitats fueron utilizados en la proporción esperada basada en la disponibilidad. A inicios del verano el húmedo zacatal fue preferencialmente usado mientras que el zacatal seco fue evitado. El grado relativo de exposición del viento puede explicar porque en el invierno los caballos pasaron menos tiempo del esperado en marismas expuestas y más tiempo del esperado en los bosques. La disponibilidad de agua fresca y halófitas puede explicar porque en verano los caballos pasaron más tiempo del esperado en el zacatal húmedo y menos tiempo en el zacatal seco. Las preferencia estacionales del hábitat deben ser consideradas cuando se maneja la sustentabilidad del ecosistema de los caballos salvajes de las islas costeras.

Overgrazing is of particular concern on barrier islands because the remaining intact systems (mostly in public ownership) are relatively rare (Schafale and Weakley 1990, Bellis 1995).

On the Currituck Banks of North Carolina and Virginia, restricting grazing access of feral horses to public land is being considered because horses are grazing on shrubbery of coastal homeowners. Public resource agencies are, in turn, concerned about potential grazing impacts to coastal resources. However, nothing was known about their foraging habitats or habitat preferences. Therefore, our objective was to obtain information on the relative preference for forage species, by season, and seasonal utilization of forage habitat. 


\section{Methods}

The study area was a $30-\mathrm{km}$ section of a barrier peninsula extending from the northern end of Back Bay National Wildlife Refuge in Virginia $\left(36^{\circ} 39.6 \mathrm{~N}\right.$, $\left.75^{\circ} 54.7 \mathrm{~S}\right)$ to Corolla, N.C. $\left(36^{\circ} 23.3 \mathrm{~N}\right.$, $\left.75^{\circ} 49.7 \mathrm{~S}\right)$, bounded on the east by the Atlantic Ocean and on the west by Currituck Sound, a distance ranging between $1.0-2.5 \mathrm{~km}$. Currituck Sound is an unusual barrier island lagoon system in that its water is fresh.

The entire study area encompassed 4,619 ha. Approximately $40 \%$ (1,875 ha) of the area is managed by public resource agencies in scattered units: Back Bay National Wildlife Refuge (managed by the U.S. Fish and Wildlife Service), False Cape State Park (managed by the state park system of Virginia), and N.C. Estuarine Research Reserve (managed by the state of North Carolina). The remaining land is owned by individuals, corporations, and The Nature Conservancy (a private land-conservation organization).

Horses have access to the entire width of the peninsula from sound to ocean, but are restricted by ocean-to-sound fences along both the northern and southern ends. Although several small communities of primarily summer homes exist along one stretch of the barrier spit, there are no paved roads. Access is by 4 -wheel drive vehicle along the seaward beach or by boat from Currituck Sound.

Ground surveys occurred during daylight hours over 5-day periods on 3 occasions in 1997: 24-28 February (late winter), 14-18 April (spring), and 16-20 June (early summer). The late-winter survey occurred when potential forage plant biomass was most likely at an annual low. The spring survey occurred near the probable peak in primary production. The early-summer survey period generally coincided with warmer temperatures.

Aerial surveys were conducted just prior to the spring and summer on-ground surveys, except that the winter aerial survey was conducted 2 weeks later than the onground survey due to adverse flying conditions. All aerial surveys were conducted between 1000 and 1200 hours at an altitude of between 160 and $325 \mathrm{~m}$. When a group of horses was spotted, the plane circled until all horses in the group were counted and the habitat type in which they were observed was recorded. Several passes over the island were made during each aerial survey. The locations of groups of horses and number of horses per group were compared at each pass to insure that all horses that could be seen from the air had been counted. Four months prior to this study, the Corolla Wild Horse Fund conducted a thorough on-ground census of the peninsula and found 43 horses and 2 donkeys.

In analyzing foraging preferences, we assumed that the population size was 43 horses and that all horses missing during aerial surveys were located in the only closed-canopied habitat type: Maritime Forest (see below). This was considered a reasonable approach because we were able to locate the same groups of horses in the open habitat types on subsequent overflights during a given aerial survey and missing horses could only have been located in the closed-canopied forest.

Geographic Information System software was used to map habitat types from aerial photos of the study area and determine the relative amount of each habitat available for foraging (Rheinhardt and Rheinhardt 1997). Spot ground-truthing was conducted to assure that areas had been mapped correctly. Recognized habitat types (see below) followed descriptions of Schafale and Weakley (1990), except that our Maritime Forest designation included both Maritime Evergreen Forest, Maritime Deciduous Forest, and Maritime Shrub Swamp. This is because these 3 forest sub-types could not always be differentiated from the air. The 5 recognized habitat types $(4,619$ ha total) were:

1. Dune Grass (456 ha): Open habitat located on primary and secondary sand dunes fringing the seaward side of the barrier spit. Dunes were dominated by sparsely to densely-packed graminoids, including Uniola paniculata L. (sea oats), Ammophila breviligulata Fernald (American beach grass), Panicum amarum Ell. (short dune grass), and Panicum virgatum L. (panic grass).

2. Dry Grassland (1,265 ha): Open habitat located on low stable dunes and sand flats in the interior of the spit, these interior sandy areas were dominated by Spartina patens (Aiton) Muhl. (saltmeadow cordgrass), with various forbs and scattered shrubs.

3. Wet Grassland (321 ha): Open habitat located in interior, wet depressions (swales) and sand flats, these interior wetlands were dominated by herbaceous vegetation (both forb and graminoid), including Spartina patens, Juncus spp. (rushes), Scirpus spp. (bulrushes), Eleocharis spp. (spikerushes), and Fimbristylis spp. (fringed rushes).

4. Tidal Freshwater Marsh (1,510 ha): Open habitat located along Currituck
Sound ( $1,510 \mathrm{ha})$, these fringing marshes were dominated by emergent herbaceous vegetation, including Spartina cynosuroides (L.) Roth. (big cordgrass), Typha spp. (cattails), Eleocharis spp., Zizania miliacea (Michaux) Doell \& Ascherson (southern wild rice), Scirpus spp., and Juncus spp., while Phragmites australis (Cavanilles) Trinius ex Steudel (reed grass) forms dense patches in some places.

5. Maritime Forest (1,067 ha): Closed canopied habitat located on old, stabilized upland dunes and in low-lying interior areas. This habitat type included Maritime Evergreen Forest, Deciduous Forest, and Shrub Swamp. Pinus taeda L. (loblolly pine) and various Quercus spp. (oaks) dominated the canopy in upland areas. The herbaceous understory supported a sparse mixture of forbs and graminoids, including Mitchella repens L. (partridge berry), Uniola laxa (L.) BSP. (loose oats), and Panicum spp. (panic grasses). The Shrub Swamps were dense, nearly impenetrable thickets with few forb and graminoid species for horses to feed upon.

Horses occasionally grazed on lawns around houses and beside artificial canals constructed for accessing Currituck Sound. During on ground surveys, we could differentiate these areas from the habitat types within which they were imbedded. However, because developed areas were too restricted in size to accurately measure from aerial photos and during aerial surveys, it was impossible to determine whether a horse was within or outside a developed area. Therefore, developed areas (yards, roads, canals, etc.) were incorporated into the habitat types in which they were imbedded, primarily Dry Grassland and Dune Grass habitats.

Although horses could potentially access all habitat types on the barrier spit, one objective was to determine if horses preferred particular habitats over others, or shifted in their preferences among seasons. To determine this, seasonal preferences and habitat avoidance were analyzed using the log-likelihood ratio procedure (Zar 1984). The log-likelihood approach (G statistic) was used instead of Chisquare because the expected frequency of habitat utilization was small $(\mathrm{n}<5)$ for 2 habitat types (Roscoe and Byars 1971). Where the log-likelihood test showed a significant difference between expected and actual habitat utilization, the Bonferroni Z simultaneous confidence 
interval approach was used to account for experiment-wise error likely to occur from multiple tests (Neu et al. 1974, Byers and Steinhorst 1984). However, the Bonferroni approach is quite conservative, particularly because a relatively large proportion of the estimated horse population was accounted for in the surveys. Therefore, we used individual confidence intervals of $90 \%(\alpha=0.10)$ following $\mathrm{Neu}$ et al. (1974).

On-ground surveys were also conducted to determine preferences for forage species in each habitat type. Upon encountering horses, we recorded the habitat type of the patch in which they were foraging and identified all plant species upon which they were feeding. A patch was defined as a discrete area of a given habitat-type in which a horse or group of horses grazed before moving to another habitat type or to another patch more than $100 \mathrm{~m}$ away. Data were recorded for each area in which a group of horses was grazing. Direct observations varied between 5 and $20 \mathrm{~m}$ distance because horses varied in their tolerance to observation. Some horses allowed us to get very close; feeding of other horses had to be viewed with binoculars from $15-20 \mathrm{~m}$ away. Plants that could not be identified to species with binoculars were identified after the horses had moved to another area. (Horses usually left the bases of plants they ate, and those bases could be matched with other, uneaten plants in the immediate vicinity.) When identifying foraged species, we recorded them as belonging to 1 of 4 categories:

1. Grazed heavily: plant species that horses actively sought and intensely grazed within a given patch;

2. Grazed: plant species that horses did not appear to actively seek, but consumed in the process of eating heavily grazed species within a given patch.

3. Not grazed: plant species that were pre- sent within patches that horses were actively grazing, but were neither actively sought by horses nor consumed;

4. Avoided: plant species that horses appeared to actively avoid by grazing other plant species around the avoided plant or plants that were sniffed or tasted and then not eaten.

We identified all plants to species whenever possible following taxonomic nomenclature of Radford et al. (1968), except that alternative authorities were applied to Dicanthelium spp., Phragmites australis (Cav.) Trin. ex Steud., and Pityopsis graminofolia (Michaux) Shinners. Sometimes a plant was either too mutilated from being grazed upon or lacked flowering or fruiting structures necessary for identification to species level. In each case, we identified the plant to the closest taxon practicable. However, all the heavily grazed plants and most of the grazed plants were successfully identified to species level.

\section{Results}

Tidal Freshwater Marsh, Dry Grassland, and Maritime Forest together comprised $83 \%$ of the available habitat (Table 1). Dune Grass and Maritime Wet Grassland each constituted less than $10 \%$ of available habitat. For all 3 seasons, the observed utilization of habitat types did not correspond to the expected utilization based on the relative availability of habitats (Table 1). Horses appeared to prefer certain habitats and those preferences varied with season of observation.

\section{Winter Foraging}

We spotted 16 horses during the winter aerial census. This means that 27 horses were not observed from the air in the open habitats and so must have been located in Maritime Forest. More horses were located in Maritime Forest than expected (Table 2). Also, fewer horses than expected were located in Tidal Freshwater Marsh. Horses in the other habitat types were found in the proportion expected.

During the winter on-ground survey, 8 graminoid and 2 forb species were observed being grazed upon across all habitat types (Table 3 ). We were never able to locate horses in Tidal Freshwater Marsh there during our winter on-ground reconnaissances (they would have be easily spotted there), nor were we able to locate any in Maritime Forest (where they remained well-hidden).

In Dune Grass habitat, horses grazed primarily on Ammophila breviligulata, Uniola paniculata, and Panicum virgatum. Panicum amarum and Croton punctatus Jacquin (Croton) were also occasionally grazed upon. Horses consumed the tender, recently-emerged shoots of all 4 of the above graminoid species, while only old, dried shoots of the forb $C$. punctatus were consumed. Neuwly emerging shoots appeared to be the primary grazing material available on dunes in late winter. Surprisingly however, the graminoid Andropogon virginicus L. (broom sedge) was avoided. In Wet Grassland, horses primarily grazed upon Spartina patens and young, newly emerged shoots of Juncus effusus L. (soft rush). These were practically the only green graminoids available to horses in Wet Grassland during winter and so they consumed these 2 species profusely.

\section{Spring Foraging}

Thirty-eight horses were sighted during the spring aerial census. Because no horses were sighted in Wet Grassland from the air, significantly fewer horses were observed there than expected (Table 2). All other habitats contained the expected pro-

Table 1. Feral horse utilization-availability data from aerial surveys, by season. The null hypothesis that habitat was utilized in proportion to its availability was rejected $(G>9.4$ ) for all 3 seasons, (winter: $G=35.5, P \ll 0.001$ ); spring: $G=12.8, P=0.025$; summer: $G=16.7, P=0.005$ ).

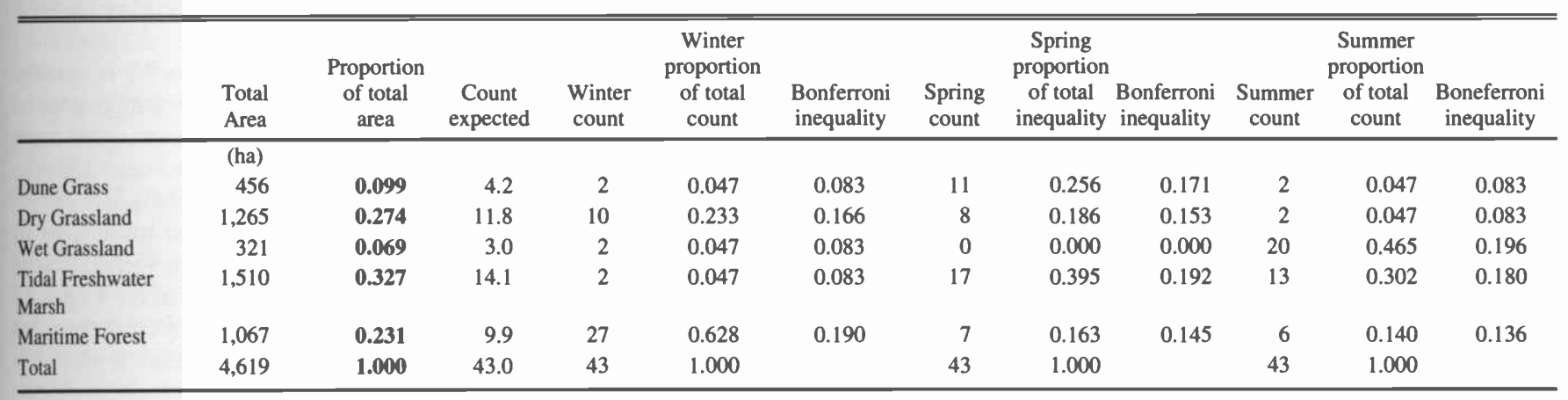




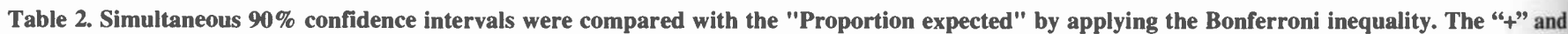

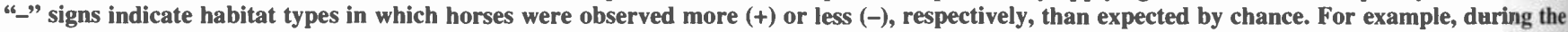

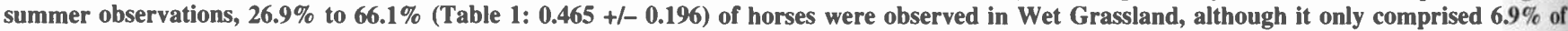
available habitat.

\begin{tabular}{|c|c|c|c|c|c|c|c|c|c|c|c|c|c|}
\hline Habitat-type & $\begin{array}{l}\text { Proportion } \\
\text { expected }\end{array}$ & & Winter & & & & Spring & & & & ammer & & \\
\hline Dune Grass & 0.099 & -0.036 & $<\mathrm{P}<$ & 0.129 & & 0.084 & $<\mathrm{P}<$ & 0.427 & & -0.036 & $<\mathrm{P}<$ & 0.129 & \\
\hline Dry Grassland & 0.274 & 0.067 & $<\mathrm{P}<$ & 0.398 & & 0.033 & $<\mathrm{P}<$ & 0.339 & & -0.036 & $<\mathrm{P}<$ & 0.129 & - \\
\hline Wet Grassland & 0.069 & -0.036 & $<\mathrm{P}<$ & 0.129 & & 0.000 & $<\mathrm{P}<$ & 0.000 & NA & 0.269 & $<\mathrm{P}<$ & 0.661 & + \\
\hline Tidal Freshwater Marsh & 0.327 & -0.036 & $<\mathrm{P}<$ & 0.129 & - & 0.203 & $<\mathrm{P}<$ & 0.587 & & 0.122 & $<\mathrm{P}<$ & 0.483 & \\
\hline Maritime Forest & 0.231 & 0.438 & $<\mathrm{P}<$ & 0.818 & + & 0.018 & $<\mathrm{P}<$ & 0.308 & & 0.003 & $<\mathrm{P}<$ & 0.276 & \\
\hline
\end{tabular}

portion of horses. Nine graminoids and 1 forb were observed being grazed upon across all habitat types (Table 3 ). Only 1 genus (Rumex sp. L.) was actively avoided.

A few horses were observed grazing in Wet Grassland during the on-ground survey. They grazed primarily upon young shoots of Juncus effusus and secondarily upon Spartina patens and Scirpus americanus Persoon. Only newly emerging Juncus spp. shoots were abundant during the spring study period. In Dry Grassland, horses grazed primarily on Dicanthelium spp. and Pityopsis graminifolia (grassleaved goldenaster). Spartina patens and Panicum virgatum were also occasionally consumed.

In spring, 8 graminoid and 1 forb species were observed being grazed upon. Vegetation in Tidal Freshwater Marsh habitat was just starting to produce new spring growth. Young shoots of Scirpus americanus and Eleocharis spp. were abundant and heavily grazed upon. Spartina patens was occasionally grazed upon, as were young, tender shoots of Typha spp., Phragmites australis, Spartina cynosuroides, and Juncus roemerianus Scheele (black needlerush).

Although 11 horses were observed in Dune Grass habitat during the spring aerial survey, they were never observed grazing there during the on-ground survey. Locating horses in the open habitat types was fairly easy because they could be seen from far away and a vehicle could be used to move quickly among groups. Locating horses was problematic in Maritime forest because the dense understory obstructed vision.

\section{Summer Foraging}

During the summer aerial census, $77 \%$ $(n=33)$ of the horses were observed in the 2 wet habitats (Wet Grassland and Tidal Freshwater Marsh). The number of horses observed in Wet Grassland was much more than expected relative to available habitat, but the number of horses in Tidal Freshwater Marsh was within the expected range (Table 2). The other habitat types also contained the number of horses expected.

Nine graminoid and 3 forb species were observed being grazed upon (Table 3 ). In Wet Grassland horses grazed primarily on Scirpus americanus, which was abundant. Occasionally, horses grazed upon Spartina patens, Eleocharis spp. (especially $E$. quadrangulata (Michaux) R. \& S.), and young shoots of Juncus roemerianus. In Tidal Freshwater Marsh habitat, horses grazed mostly on Scirpus americanus, Spartina patens, and young shoots of Spartina cynosuroides, and secondarily on Eleocharis spp. where available. In Dry Grassland habitat, horses fed primarily on the inflorescences and stems of Hypochoeris radicata L. (cat's ear), which was very abundant, and secondarily on Plantago aristata Michaux (plantain) and Pityopsis graminifolia.

In Dune Grass areas, horses grazed primarily on Uniola paniculata and secondarily on Spartina patens. However, our period of observation in dune areas was limited because we were successful in locating horses there on only 1 occasion and they bolted soon after we encountered them.

Several groups of horses were observed foraging in Developed areas during the summer study period. All of these horses were located near artificial canals connected to Currituck Sound, perhaps because fresh water was readily available there. In Developed areas, horses consumed Scirpus americanus and young shoots of Juncus effusus and J. roemerianus (both species located along the edge of canals), Plantago aristata, Dicanthelium scoparium (Lamaark) Gould (witch grass), Cynodon dactylon (L.) Persoon (Bermuda grass), and Spartina patens.

Although horses were never directly observed in Maritime Forest, a news video filmed on 13 June 1997 ( 3 days prior to the summer sampling period) showed horses grazing on Uniola laxa in Maritime Forest. Thus, horses do forage in Maritime Forest, at least during summer. Our sys- tematic surveys of Maritime Forest habitat failed to locate horses there, but $U$. laxa is abundant throughout Maritime Forest in summer.

\section{Discussion}

\section{Seasonal Foraging}

Because the area potentially accessible by horses was relatively small (4,619 ha), feral horses could easily and quickly access all available habitat on the peninsula. Further, due to the mild climate of the Outer Banks, forage was available in all habitat types during each season, albeit more abundantly during spring and summer. Thus, this study of seasonal habitat preferences concerns the relative amount of time horses spent in particular habitats among seasons.

A number of factors likely influenced habitat use on a seasonal basis, including seasonal differences affecting weather conditions (e.g., temperature extremes, wind), seasonal availability of fresh water, seasonal differences in plant phenologies, and habitat-specific conditions controlling plant distribution and abundance patterns. All of these factors likely influenced where horses concentrated foraging efforts and since these factors could not be independently controlled, this study could not differentiate the relative degree to which each factor affected seasonal preferences. However, seasonal preference patterns indicated which sets of factors might be most important in influencing the seasonal preferences.

Winter on Currituck Banks is usually windy, with a normal Feb. temperature of $5.9^{\circ} \mathrm{C}$. The fact that horses occurred more than expected in Maritime Forest and less than expected in Tidal Freshwater Marsh suggests that horses spent more time in winter seeking shelter (in forests) from wind and less time on more exposed marshes. During spring, temperatures are mild (normal Apr. temperature is $15.0^{\circ} \mathrm{C}$ ), graminoids produce vigorous new shoots, 
Table 3. Grazing intensities on identified forbs (f) and graminoids (g), by season and habitat. Abbrev.: G= grazed, GH= grazed heavily, NG= not grazed, A= avoided. G1 = only dried-out shoots consumed; G2, GH2 = only young, tender, new shoots consumed.

\begin{tabular}{|c|c|c|c|c|c|c|c|c|c|c|c|}
\hline & \multirow[t]{2}{*}{ Life-form } & \multirow[b]{2}{*}{$\begin{array}{l}\text { Dune } \\
\text { Grass }\end{array}$} & \multicolumn{2}{|c|}{ Winter } & \multicolumn{2}{|c|}{ Spring } & \multirow[b]{2}{*}{$\begin{array}{l}\text { Tidal } \\
\text { Fresh- } \\
\text { water } \\
\text { Marsh }\end{array}$} & \multicolumn{4}{|c|}{ Summer } \\
\hline & & & $\begin{array}{l}\text { Dry } \\
\text { Grassland }\end{array}$ & $\begin{array}{l}\text { Wet } \\
\text { Grassland }\end{array}$ & $\begin{array}{l}\text { Dry } \\
\text { Grassland }\end{array}$ & $\begin{array}{c}\text { Wet } \\
\text { Grassland }\end{array}$ & & $\begin{array}{l}\text { Dune } \\
\text { Grass }\end{array}$ & $\begin{array}{l}\text { Dry } \\
\text { Grassland }\end{array}$ & $\begin{array}{l}\text { Wet } \\
\text { Grassland }\end{array}$ & $\begin{array}{l}\text { Fresh- } \\
\text { water } \\
\text { Marsh }\end{array}$ \\
\hline $\begin{array}{l}\text { Ammophila breviligulata } \\
\text { Fernald }\end{array}$ & $g$ & $\mathrm{GH}$ & & & & & & & & & \\
\hline Andropogon virginicus $\mathrm{L}$. & $g$ & A & & & & & & & NG & & \\
\hline Carex sp. L. & $g$ & & & & & & & & & & \\
\hline Cakile edentula (Bigelow) Hooker & f & NG & & & & & & NG & & & \\
\hline Cenchrus tribuloides $\mathrm{L}$. & $g$ & NG & & & & & & & & & \\
\hline Croton punctatus Jacquin & $f$ & G1 & G & & & & & & & & \\
\hline Cynodon dactylon (L.) Persoon & $g$ & & & & & & & & & & \\
\hline $\begin{array}{l}\text { Dicanthelium scoparium } \\
\text { (Lamaark) Gould }\end{array}$ & $g$ & & & & & & & & & & \\
\hline $\begin{array}{l}\text { Dicanthelium spp. (A.S. } \\
\text { Hitchoock \& Chase) Gould }\end{array}$ & $g$ & & GH & & GH & & & & & & \\
\hline $\begin{array}{l}\text { Dichromena colorata (L.) } \\
\text { Hitchoock }\end{array}$ & $g$ & & & & & & & & & & \\
\hline Eleocharis spp. R. Brown & $g$ & & & & & & GH & & & G & G \\
\hline $\begin{array}{l}\text { Eleocharis quadrangulata (g } \\
\text { Michaux) R. \& S. }\end{array}$ & & & & & & & & & G & & \\
\hline Fimbristylis sp. Vahl & $g$ & & & & & & & & & NG & \\
\hline Heterotheca sp. Cassini & $f$ & & G & & & & & & & & \\
\hline Hypochoeris radicata $\mathrm{L}$. & $f$ & & & & & & & & GH & & \\
\hline Juncus effusus L. & $g$ & & & & & GH & & & & & \\
\hline $\begin{array}{l}\text { Juncus roemerianus } \\
\text { Scheele }\end{array}$ & $g$ & & & & & & NG & & & G2 & NG \\
\hline Oenothera sp. L. & $f$ & & & & & & & & NG & & \\
\hline $\begin{array}{l}\text { Opuntia drummondii } \\
\text { Graham }\end{array}$ & $f$ & & NG & & NG & & & & NG & & \\
\hline Panicum amarum Ell. & $g$ & G & & & & & & & & & \\
\hline Panicum virgatum $\mathrm{L}$. & $g$ & GH & & & G & & & & & & \\
\hline $\begin{array}{l}\text { Phragmites australis } \\
\text { (Cavanilles) Trinius ex Steudel }\end{array}$ & $g$ & & & & & & & & & & \\
\hline $\begin{array}{l}\text { Pityopsis graminifolia } \\
\text { (Michaux) Nuttall }\end{array}$ & $f$ & & & & GH & & & & G & & \\
\hline Plantago aristata Michaux & $f$ & & & & & & & & G & & \\
\hline Polygonum sp. L. & $f$ & & & & & & & & & NG & \\
\hline Ranunculus bulbosus $\mathrm{L}$. & $f$ & & & & & & & & NG & & \\
\hline Rumex sp. L. & $f$ & & & & A & & & & & & \\
\hline Scirpus americanus Persoon & $g$ & & & & & G & GH & & & GH & GH \\
\hline $\begin{array}{l}\text { Setaria geniculata (Lam.) } \\
\text { Beauvois }\end{array}$ & $g$ & & & & & & & & & & NG \\
\hline Solidago sp. L. & $f$ & & & & NG & & & & & & \\
\hline Spartina cynosuroides (L.) Roth. & $g$ & & & & & & G2 & & & & $\mathrm{GH} 2$ \\
\hline Spartina patens (Aiton) Muhl. & $g$ & & GH & $\mathrm{GH}$ & G & G & G & G & & G & GH \\
\hline Stellaria media (L.) Cyrillo. & $f$ & & & & & & & & & & \\
\hline Thelypteris palustris Schott & $f$ & & & & & & NG & & & & \\
\hline Typha latifolia L. & $g$ & & & & & & G2 & & & & NG \\
\hline Typha sp. L. & $g$ & & & & & & & & & NG & \\
\hline Uniola paniculata $\mathrm{L}$. & $g$ & $\mathrm{GH}$ & & & & & & $\mathrm{GH}$ & & & \\
\hline $\begin{array}{l}\text { Zizaniopsis miliacea (Michaux) } \\
\text { Doell \& Ascherson }\end{array}$ & $g$ & & & & & & NG & & & & \\
\hline
\end{tabular}

and horses forage among all available habitats in the expected proportions. (The negative association with Wet Grassland in spring was due to there being no horses sighted there, a not unlikely result consid- ering that the expected number was only 2.) In summer, when temperatures are hot (normal Jun. temperature is $24.2^{\circ} \mathrm{C}$ ), horses seemed to concentrate more than expected in Wet Grassland and less than expected in Dry Grassland. Not only were forage plants abundant in Wet Grassland habitat in early summer, but fresh drinking water was prevalent there as well. Thus, horses tended to spend more time foraging 
near water and less time in hot, open, Dry Grassland habitat.

Other studies of habitat preference in the western USA show that feral horses preferentially choose habitats close to water sources (Hansen 1976, Miller 1983, Crane et al. 1997). Feral horse populations on other barrier islands (e.g., Assateague Island (Maryland), Shackleford Banks (North Carolina), Cumberland Island (Georgia)) are surrounded by saline water and so freshwater is limited to ephemeral pools in swales and in consumed vegetation. On such barrier islands, fresh water is a limiting resource for which horses compete, particularly in summer (Wood et al. 1987). In contrast, fresh water is available all year in Currituck Sound.

In all seasons, horses sought and most actively consumed a relatively restricted number of plant species, primarily graminoids, and preferences for specific species varied among seasons. For example, Typha latifolia L. was grazed upon in spring when emerging shoots were tender, but not consumed in summer after stalks had hardened. Likewise, horses concentrated on tender, new shoots of Juncus roemerianus in late winter and early spring, but not on older, tougher stems in summer.

\section{Effects of Grazing on Native Vegetation}

Grazing by horses appeared to impact native vegetation, but impacts varied by habitat and season. Grazing impacts in Dry Grassland were particularly notable at the end of winter when available forage would have been expected to be at its lowest biomass for the year. In winter, some areas of Dry Grassland seemed to support full-statured plants only in difficult-tograze areas, such as under dense, overhanging shrubs. Grazing impacts were also substantial in Tidal Freshwater Marsh in early spring, at the time graminoids were just beginning to sprout. However, trampling may have a greater negative impact than grazing, per se. On Cumberland Island, trampling by feral horses was more detrimental to salt marsh production than grazing (Turner 1987). By summer, grazing impacts were less noticeable throughout the study area, perhaps because grazing pressure did not keep pace with production of forage by late spring and summer.

\section{Management Implications}

State, federal, and private natural resource agencies with land on Currituck Banks are concerned about the detrimental impacts free-roaming horses may be having on native vegetation. Private landowners are concerned about horses foraging on planted shrubbery. Both concerns will exacerbate as residential development expands further. One management option being considered is fencing in the horses. This option would alleviate the impacts on residential property, but could increase impacts to native vegetation if horse density increases within the fenced area.

Horses impact native vegetation, primarily via cropping and trampling. However, horses consume few forb species and graminoid species seem to recover from grazing by early summer when primary production is highest. However, non-grazed areas were not available for comparison and horse density was not manipulated, and so the degree of impact could not be quantified.

Exclosure studies would be required to determine how grazing and trampling impacts affect the long-term structure and/or composition of native vegetation. Because rooting impacts of feral hogs may be more severe than horse grazing impacts on Currituck Banks, exclosure experiments would have to be designed to separate horse grazing from hog rooting impacts.

At this time, feral horse population density (approximately 1 horse per $\mathrm{km}^{2}$ ) appears to be below the carrying capacity of their current range. Due to an abundance of fresh water and a diversity of graminoid-dominated habitat types, feral horses have maintained a stable population for at least the past $40-50$ years. We would have expected the population to increase over the past half century. We suspect that the herd has been periodically culled (sold off-island) by local inhabitants.

Should horse density increase or carrying capacity decline (by fencing), grazing and trampling impacts could increase substantially and lead to resource degradation. To maintain a healthy and sustainable population, horse density and availability of habitat must also be considered within the context of horse social structure, population dynamics, and genetic diversity. Therefore, information on the population ecology of Currituck horses is needed to effectively manage the feral horses and their resource base.

\section{Literature Cited}

Bellis, V. J. 1995. Ecology of maritime forests of the southern Atlantic coast: a community profile. U.S. Dept. of the Interior Biol.Rep. 30. Tech. Infor. Serv., Springfield, Virg.
Byers, C. R. and R. K. Steinhorst. 1984. Clarification of a technique for analysis of utilization-availability data. J. Wildl Manage. 48:1050-1053.

Cook, C. W. 1975. Wild horses and burros: new management problem. Rangeman's J 2:19-21.

Crane, K. K., M. A. Smith, and D. Reynolds 1997. Habitat selection patterns of feral horses in southcentral Wyoming. J. Range Manage. 50:374-380.

Hansen, R. M. 1976. Foods of free-roaming horse in southern New Mexico. J. Range Manage. 29:347.

Miller, R. 1983. Habitat-use of feral horses and cattle in Wyoming's Red Desert. J. Range Manage. 36:195-199.

Neu, C. W., C. R. Byers, and J. M. Peek. 1974. A technique for analysis of utilizationavailability data J. Wildl. Manage 38:541-545.

Radford, A. E., H. E. Ahles, and C. R. Bell. 1968. Manual of the vascular flora of the Carolinas. University of North Carolina Press, Chapel Hill, N.C.

Rheinhardt, R.D. and M.C. Rheinhardt. 1997. Habitat-use of feral horses on Currituck Banks, North Carolina. Rep to North Carolina National Estuarine Res. Reserve, Raleigh, N.C.

Roscoe, J. T. and J. A. Byars. 1971. An investigation of the restraints with respect to sample size commonly imposed on the use of the Chi-Square statistic. J. Americ. Statist. Assoc. 66:755-759.

Schafale, M. P. and S. A. Weakley. 1990. Classification of the Natural Communities of North Carolina: Third Approximation. North Carolina Natural Heritage Program, Div. of Parks and Recr., Raleigh, N.C.

Turner, M. G. 1987. Effects of grazing by feral horses, clipping, trampling, and burning on a Georgia salt marsh. Estuaries 10:54-60.

Wood, G.W, M.T. Mengak, and M. Murphy. 1987. Ecological importance of feral ungulates at Shackleford Banks, North Carolina. Americ. Midl. Nat. 1 18:236-244.

Zar, J. H. 1984. Biostatistical Analysis. Second edition. Prentis-Hall, Englewood Cliffs, N.J. 